University of Nebraska - Lincoln

DigitalCommons@University of Nebraska - Lincoln

Nebraska Cooperative Fish \& Wildlife Research Nebraska Cooperative Fish \& Wildlife Research Unit -- Staff Publications

2013

\title{
The Feasibility of Producing Adequate Feedstock for Year-Round Cellulosic Ethanol Production in an Intensive Agricultural Fuelshed
}

\author{
Daniel R. Uden \\ University of Nebraska-Lincoln, danielruden87@gmail.com \\ Robert B. Mitchell \\ USDA-ARS, University of Nebraska-Lincoln, rob.mitchell@ars.usda.gov \\ Craig R. Allen \\ University of Nebraska-Lincoln, callen3@unl.edu \\ Qingfeng Guan \\ China University of Geosciences (Wuhan) \\ Tim D. McCoy \\ Nebraska Game and Parks Commission, tim.mccoy@nebraska.gov \\ Follow this and additional works at: https://digitalcommons.unl.edu/ncfwrustaff \\ Part of the Aquaculture and Fisheries Commons, Environmental Indicators and Impact Assessment \\ Commons, Environmental Monitoring Commons, Natural Resource Economics Commons, Natural \\ Resources and Conservation Commons, and the Water Resource Management Commons
}

Uden, Daniel R.; Mitchell, Robert B.; Allen, Craig R.; Guan, Qingfeng; and McCoy, Tim D., "The Feasibility of Producing Adequate Feedstock for Year-Round Cellulosic Ethanol Production in an Intensive Agricultural Fuelshed" (2013). Nebraska Cooperative Fish \& Wildlife Research Unit -- Staff Publications. 112. https://digitalcommons.unl.edu/ncfwrustaff/112

This Article is brought to you for free and open access by the Nebraska Cooperative Fish \& Wildlife Research Unit at DigitalCommons@University of Nebraska - Lincoln. It has been accepted for inclusion in Nebraska Cooperative Fish \& Wildlife Research Unit -- Staff Publications by an authorized administrator of DigitalCommons@University of Nebraska - Lincoln. 


\title{
The Feasibility of Producing Adequate Feedstock for Year-Round Cellulosic Ethanol Production in an Intensive Agricultural Fuelshed
}

\author{
Daniel R. Uden • Rob B. Mitchell • Craig R. Allen • \\ Qingfeng Guan • Tim D. McCoy
}

Published online: 22 March 2013

(C) Springer Science+Business Media New York 2013

\begin{abstract}
To date, cellulosic ethanol production has not been commercialized in the United States. However, government mandates aimed at increasing second-generation biofuel production could spur exploratory development in the cellulosic ethanol industry. We conducted an in-depth analysis of the fuelshed surrounding a starch-based ethanol plant near York, Nebraska that has the potential for cellulosic ethanol production. To assess the feasibility of supplying adequate biomass for year-round cellulosic ethanol production from residual maize (Zea mays) stover and bioenergy switchgrass (Panicum virgatum) within a 40-km road network service area of the existing ethanol plant, we identified $\sim 14,000$ ha of marginally productive cropland within the service area suitable for conversion from annual rowcrops to switchgrass and $\sim 132,000$ ha of maize-enrolled cropland from which maize
\end{abstract}

D. R. Uden $(\bowtie)$

Nebraska Cooperative Fish and Wildlife Research Unit,

School of Natural Resources, University of Nebraska-Lincoln,

3310 Holdrege Street,

Lincoln, NE 68583, USA

e-mail: danielruden87@gmail.com

R. B. Mitchell

USDA-ARS Grain, Forage and Bioenergy Research Unit,

University of Nebraska-Lincoln, 130 Keim Hall,

Lincoln, NE 68583, USA

C. R. Allen

US Geological Survey, Nebraska Cooperative Fish and Wildlife Research Unit, School of Natural Resources,

University of Nebraska-Lincoln, 3310 Holdrege Street,

Lincoln, NE 68583, USA

Q. Guan

Faculty of Information Engineering, China University

of Geosciences (Wuhan), Wuhan, Hubei 430074, China

T. D. McCoy

Nebraska Game and Parks Commission, 2200 North 33rd Street,

Lincoln, NE 68503, USA stover could be collected. Annual maize stover and switchgrass biomass supplies within the $40-\mathrm{km}$ service area could range between 429,000 and 752,000 metric tons (mT). Approximately 140-250 million liters (1) of cellulosic ethanol could be produced, rivaling the current 208 million 1 annual starch-based ethanol production capacity of the plant. We conclude that sufficient quantities of biomass could be produced from maize stover and switchgrass near the plant to support year-round cellulosic ethanol production at current feedstock yields, sustainable removal rates and bioconversion efficiencies. Modifying existing starch-based ethanol plants in intensive agricultural fuelsheds could increase ethanol output, return marginally productive cropland to perennial vegetation, and remove maize stover from productive cropland to meet feedstock demand.

Keywords Switchgrass · Maize stover · Cellulosic ethanol · Biomass $\cdot$ Feasibility $\cdot$ Fuelshed

\section{Introduction}

The United States ethanol industry has developed significantly since production was initiated in the 1980s [1]. Despite extensive development, the production of starchbased ethanol from maize (Zea mays) grain remains controversial, due to uncertainties over its net energy production, greenhouse gas emissions and competition with food production for landuse [2]. The potential economic, environmental and ecological benefits of second-generation biofuels are increasingly promoted [3], and the production of cellulosic ethanol from plant biomass is the subject of continuing research $[4,5]$.

Cellulosic ethanol production has not yet been implemented on a commercial scale in the United States, due to a variety of factors, including a lack of infrastructure for converting plant 
biomass to ethanol [5]. However, United States government mandates aimed at increasing second-generation biofuel production [6] could spur exploratory development. For example, print media has reported the Abengoa Bioenergy ethanol plant near York, Nebraska has been identified as a potential candidate for cellulosic ethanol development in the future [7]. Currently, only starch-based ethanol is produced at the plant [7].

Although a variety of plant materials can be converted into cellulosic ethanol, few of them are available in adequate quantities to meet the feedstocks demands of a commercial scale plant. Maize stover is a readily available feedstock for ethanol plants located in rowcrop-dominated areas [8], and is defined as all non-grain, aboveground portions of the maize plant [9]. Although as much as $75 \%$ of maize stover can be removed annually from fields with conventional farm machinery, only $30-50 \%$ of maize stover can be sustainably removed $[8,10]$. Retaining some residual stover in fields is necessary for preventing erosion and maintaining soil health $[10,11]$; therefore, sustainable removal rates may vary locally according to slope and existing soil organic matter, as noted by Graham et al. [8]. If ethanol plants in rowcrop-dominated landscapes do initiate cellulosic ethanol production, it is likely that maize stover would be the primary feedstock initially supplied to them [7], although alternative feedstocks could supplement stover in subsequent years.

Switchgrass (Panicum virgatum) is an alternative biofuel feedstock that could supplement maize stover for cellulosic ethanol production and provide economic and environmental benefits $[12,13]$. Simple sugars from switchgrass cell walls can be fermented to produce cellulosic ethanol $[4,14]$. Economically, switchgrass is a relatively drought-tolerant crop $[15,16]$, produces large quantities of biomass on marginally productive croplands $[4,15]$, requires less water and chemical input than annual rowcrops [13], requires less intensive management than annual rowcrops, and could help diversify farmer income [13, 17, 18]. Environmentally, switchgrass is a near carbon-neutral fuel source $[19,20]$ that releases less carbon into the atmosphere than traditional rowcrop cultivation [21] and sequesters carbon in prairie soils $[13,15,19]$. Perennial grasses like switchgrass are common components of Conservation Reserve Program (CRP) plantings and have been promoted for reducing soil erosion and protecting water resources [22]. Switchgrass is also a net energy positive fuel source [4]. While switchgrass is not likely to replace annual rowcrops on productive soils or irrigated fields, due to the profitability associated with raising rowcrops under favorable conditions, it could replace rowcrops on nonirrigated, marginally productive agricultural lands.

Marginally productive agricultural lands can include small, complexly shaped, non-irrigated portions of agricultural fields [5]. However, soil type, mean annual precipitation, and irrigation limitations could be important identifiers of marginally productive croplands. Some non-irrigated fields may be productive if they receive adequate precipitation and lie on fertile soils, and therefore should not be considered marginal. Alternatively, larger, non-irrigated fields on poor soils and in dry areas could be considered marginally productive. Although agricultural productivity is likely to influence landuse, individual farmers decide how to manage their land, and therefore, not all marginally productive fields may be converted to bioenergy production. Furthermore, forecasts of future biofuel-based landuse conversions are complicated by the fact that individual landowner decisions are difficult to predict.

It is unclear if sufficient quantities of biomass can be sustainably produced in close proximity to ethanol plants to support year-round cellulosic ethanol production. In this study, we assessed the feasibility of producing adequate feedstock quantities from maize stover and switchgrass for year-round cellulosic ethanol production in a 40-km service area around an operating starch-based ethanol plant near York, NE, USA. We employed a conservative approach in identifying marginally productive rowcrop fields that could be converted to switchgrass, estimated potential switchgrass and maize stover biomass supplies that could be sustainably removed annually, projected cellulosic ethanol yield at current feedstock bioconversion efficiencies, and compared annual cellulosic ethanol yield potential to current annual starch-based ethanol plant production capacities.

\section{Methods}

\section{Study Area}

The 40-km service area centered on an existing starch-based ethanol plant operated by Abengoa Bioenergy encompasses portions of Butler, Polk, Seward, and York counties in the Rainwater Basin region of south-central Nebraska, where both irrigation and dryland farming are common. Groundwater for rowcrop irrigation is obtained from underlying aquifers [23]. The majority of the agricultural landscape is used for maize and soybean (Glycine max) production, although small grain farming and cattle ranching are conducted on smaller scales $[24,25]$.

\section{Data Sources}

Agricultural irrigation type GIS data were provided by the Rainwater Basin Joint Venture (http://www.rwbjv.org), and Nebraska roads GIS data were downloaded online from the Nebraska Department of Natural Resources (http://dnr.ne.gov/ databank/statewide.html). Geographic coordinates of the Abengoa ethanol plant location were obtained from Google Earth (http://www.google.com/earth/index.html) satellite imagery and digitized in ArcGIS (http://www.esri.com). Average 
2010 maize grain yields for Butler, Polk, Seward, and York counties were obtained from the National Agricultural Statistics Service (http://www.nass.usda.gov). Prior to analysis, all GIS data layers were projected in the North American Datum 1983 Universal Transverse Mercator Zone 14 North coordinate system.

\section{Agricultural Landuse}

Within the $40-\mathrm{km}$ plant service area, rowcrop fields were grouped into 4 irrigation types: center-pivot irrigated, pivot corners, gravity irrigated and dryland fields. A center-pivot is a large sprinkler system generally anchored at a field center point and connected to a groundwater well. Groundwater is pumped through a pipe extending from the field center to the least distant field perimeter, with multiple two-wheeled moving towers supporting the pipe along its extent. As the centerpivot moves in a circular motion around the field, sprinklers connected to the pipe release water to the soil surface. Pivot corners result from irrigating square shaped agricultural fields with circular center-pivot irrigation patterns. Because centerpivots fail to move across pivot corners, the corners are not supplied with water. A typical center-pivot irrigation system is centered on a square quarter section ( $\sim 64$ ha, 160 acres) and irrigates only 53 ha (132 acres), leaving 11 ha (28 acres) of rainfed cropland in the four corners [5]. Several means of irrigating pivot corners exist, including center-pivot corner systems or lateral irrigation pipes. Farmers in the Rainwater Basin commonly raise crops on pivot corners without irrigation. A gravity irrigation system consists of a temporary lateral irrigation line extending along the field edge with the greatest altitude and perpendicular to the direction of crop rows. Water from lateral lines is released into furrows between crop rows and is pulled by the force of gravity toward the opposite end of the field. A dryland field is not irrigated by any means. In regions and years with adequate growing season precipitation, dryland field and pivot corner grain yields are comparable with irrigated croplands; however, in drier years, non-irrigated fields yield less.

\section{Modeling Landuse Change}

Landuse change forecasts are complicated by the fact that individual landowner decisions are difficult to predict. Neural networks and other artificial intelligence methods are useful for predicting land use and landcover change (LULCC) in urban and agricultural settings [26, 27]; however, these approaches often rely on the availability of historical landcover data for model training, which is not available for bioenergy switchgrass in the Great Plains. Therefore, we developed a simple agent-based model for forecasting biofuel-based landuse change in the Rainwater Basin region. An agent-based model is a bottom-up approach for simulating decisions of individual agents within a system [28, 29], and it does not necessarily rely on historical data. In this study, agents consisted of landowners, and their decision to convert marginally productive rowcrop fields to switchgrass was determined by a simple set of rules and random processes. Individual rowcrop fields were grouped into marginality classes, according to the number of marginal characteristics they possessed, and set percentages of fields within each marginality class were randomly converted to switchgrass. Although our modeling approach is simple, it is conservative in that it allows some fields with multiple marginal characteristics to remain in rowcrop production. Furthermore, the overall method we employed could facilitate more complex methods of modeling LULCC, as long as the methods designate individual land parcels for conversion to switchgrass.

\section{Cropland Classification}

A list of characteristics making agricultural fields in the Rainwater Basin region of Nebraska, USA, suitable for conversion from annual rowcrops to switchgrass was compiled and consisted of irrigation type, agricultural suitability of underlying soils, field size and shape complexity, mean annual precipitation, and relative risk of experiencing additional irrigation limitations in the future. Each field was assigned to 1 of 24 marginality classes, based on the number of marginal characteristics it possessed. The more marginal characteristics a field possessed, the more suitable it was considered for conversion from rowcrops to switchgrass.

Dryland fields and pivot corners were considered more marginal and suitable for conversion to switchgrass than gravity and center-pivot irrigated fields, due to the lack of irrigation systems on dryland fields and pivot corners and the fact that switchgrass is more drought-tolerant and water use efficient than maize [30]. Fields were also classified according to the agricultural suitability of soils underlying field center points. The USDA Natural Resources Conservation Service (NRCS) groups soils into land capability classes, based on their suitability for agricultural production. Soils in classes 1 and 2 are considered most suitable for agriculture, while soils in classes 7 and 8 are considered completely unsuitable. Soils in classes 3 , 4, 5 and 6 can be described as marginally productive agricultural lands, and may be better suited to less intensive forms of agricultural landuse, which could include seeding with perennial grasses like switchgrass that remain productive on poor soils [4]. Rainwater Basin fields located on soils in NRCS land capability classes $3,4,5$ or 6 were considered more marginal than fields with soils in classes 1 or 2 .

Small, complexly shaped dryland fields were considered more marginal than larger, more uniformly shaped dryland fields. Farming rowcrops on small, complexly shaped fields with increasingly large, modern farm equipment can be inconvenient and time consuming, and these fields could be 
better suited to raising less management intensive switchgrass stands. Area was used to compare field size and shape index was used to compare field shape complexity. Shape index is calculated by dividing the perimeter of a shape by the perimeter of the most compact form of that shape. Greater shape indices indicate more complex shapes. All Rainwater Basin pivot corners were considered marginal, due to their small areas, as were dryland fields with areas less than the mean pivot corner area (3.7 ha). Dryland fields with areas greater than 3.7 ha, but less than the 25 th percentile value for dryland field area (4.7 ha), and with a shape index greater than the 75 th percentile value for dryland field shape index (1.56), were considered more marginal than larger and more uniformly shaped dryland fields.

Mean annual precipitation and the potential for additional irrigation limitations were characteristics used to identify marginally productive croplands throughout the Rainwater Basin region. These factors did not vary enough within the existing starch-based ethanol plant $40-\mathrm{km}$ service area to differentiate between marginal and non-marginal fields. However, because the marginal field identification process was performed for the entire Rainwater Basin region and results were restricted to the existing starch-based ethanol plant service area, the factors were considered part of the identification process in this analysis. Due to the rain shadow effect of the Rocky Mountains, precipitation increases from west to east across the Rainwater Basin, with drier areas located in the western half [31]. Fields in areas with a mean annual precipitation $\leq 63.5 \mathrm{~cm}$ were considered dry and more marginal than fields in areas with a mean annual precipitation $>63.5 \mathrm{~cm}$, because rowcrop productivity tends to decrease under drier conditions. Finally, center-pivot irrigated and gravity irrigated fields were classified according to their potential to experience additional irrigation limitations in the future. Fields were assigned to a high risk or low risk category, based on the Natural Resource District in which they were located. NRDs with histories of implementing limitations were grouped and classified as being at high risk for additional irrigation limitations, whereas those without previously implemented moratoriums or stays were combined and classified as being at low risk for future limitations. If NRDs restrict agricultural irrigation in these regions in the future, switchgrass could replace rowcrops on some previously irrigated fields.

Rainwater Basin croplands classified as most marginally productive and suitable for conversion to switchgrass were pivot corners and small, complexly shaped dryland fields, located on soils in NRCS land capability classes 3, 4, 5, or 6 and in areas with annual average precipitation $\leq 63.5 \mathrm{~cm}$. Croplands classified as least marginal and unsuitable for conversion to switchgrass were gravity and pivot irrigated fields, and large, uniformly shaped dryland fields located on soils in NRCS land capability classes 1 or 2 , in areas with annual average precipitation $>63.5 \mathrm{~cm}$ and at low risk of experiencing irrigation limitations. Remaining croplands were placed into intermediate classes according to the number of marginal criteria they satisfied (Table 1).

\section{GIS Analysis}

The geostatistical analyst extension in ArcGIS was used to assign percentages of Rainwater Basin fields in different marginality classes to be converted to switchgrass. We used an arbitrary, but conservative, approach in assigning conversion percentages, acknowledging that individual landowner decisions are difficult to predict. Greater conversion percentages were assigned to classes of fields that possessed more marginal characteristics, and only classes possessing all marginal characteristics had $100 \%$ of fields converted to switchgrass. Classes possessing fewer marginal characteristics were assigned lower switchgrass conversion percentages of $75,50,25$ or 0 . Fields not assigned to switchgrass conversion were assumed to remain in rowcrop production. This conservative approach ensured that only proportions of Rainwater Basin rowcrop fields satisfying at least one, but not all, of the marginal criteria were converted to switchgrass in the simulation.

The Network Analyst extension in ArcGIS was used to generate a 40-km service area for an existing starch-based ethanol plant, using all Nebraska roads as travel corridors (Fig. 1). Forty kilometers is recognized as the approximate maximum distance producers may be willing to transport grain or other feedstocks to biorefineries for processing $[5,32]$. The existing starch-based ethanol plant service area overlaps with $40-\mathrm{km}$ service areas of three neighboring starch-based ethanol plants. However, the plant service areas were allowed to encroach into neighboring plant service areas, since none of these plants have been identified as cellulosic ethanol producers in the near future.

Shapefiles representing Rainwater Basin croplands converted to switchgrass in each of the 24 marginality classes were combined into a single shapefile. Shapefiles representing remaining rowcrops were combined similarly. Total rowcrop and switchgrass shapefiles for the entire Rainwater Basin region were restricted to the previously generated $40-\mathrm{km}$ service area for the existing starch-based ethanol plant (Fig. 2), and resulting rowcrop and switchgrass shapefiles were converted from vector to raster format. Resulting raster layers were reclassified into single classes and total bioenergy switchgrass and rowcrop areas were obtained by inputting reclassified rasters into the program Fragstats (http://www.umass.edu/landeco/research/ fragstats/fragstats.html).

\section{Biomass Supplies}

Total maize-enrolled hectares in the service area was calculated by multiplying the number of hectares remaining in 
Table 1 List of 24 rowcrop field marginality classes and percentages of classes converted to switchgrass in the $40-\mathrm{km}$ service area of an existing starch-based ethanol plant. Conversion percentages of $0,25,50,75$ or 100 were assigned to marginality classes, according to the number of marginal characteristics fields composing the class possessed. Lack of irrigation infrastructure on pivot corners and dryland fields, the small size and complex shape of some dryland fields, poor agricultural soil suitability, decreased precipitation, and high risk of additional irrigation limitations were all considered marginal characteristics
Landuse classification

Conversion (\%)

Pivot corners + poor soils + dry area

Pivot corners + poor soils + wet area

75

Pivot corners + good soils + dry area

Pivot corners + good soils + wet area

Small dryland fields + poor soils + dry area

Small dryland fields + poor soils + wet area

Small dryland fields + good soils + dry area

Small dryland fields + good soils + wet area

Large dryland fields + poor soils + dry area

Large dryland fields + poor soils + wet area

0

Large dryland fields + good soils + dry area

Large dryland fields + good soils + wet area 0

Gravity + poor soils + dry area + high risk of irrigation limitations $\quad 0$

Gravity + poor soils + wet area + high risk of irrigation limitations $\quad 0$

Gravity + good soils + dry area + high risk of irrigation limitations 0

Gravity + good soils + wet area + high risk of irrigation limitations 0

Gravity + poor soils + wet area + low risk of irrigation limitations $\quad 0$

Gravity + good soils + wet area + low risk of irrigation limitations $\quad 0$

Pivots + poor soils + dry area + high risk of irrigation limitations $\quad 0$

$\begin{array}{ll}\text { Pivots }+ \text { poor soils }+ \text { wet area }+ \text { high risk of irrigation limitations } & 0\end{array}$

Pivots + good soils + dry area + high risk of irrigation limitations $\quad 0$

Pivots + good soils + wet area + high risk of irrigation limitations $\quad 0$

Pivots + poor soils + dry area + low risk of irrigation limitations $\quad 0$

Pivots + good soils + wet area + low risk of irrigation limitations $\quad 0$

Fig. 1 Current major landcover classes within a $40-\mathrm{km}$ road network service area of an existing starch-based ethanol plant near York, Nebraska. Rowcrops are the aggregation of all irrigated and non-irrigated rowcrop fields from Rainwater Basin Joint Venture (RWBJV) 2006 agricultural irrigation type data. This figure was created in ArcGIS

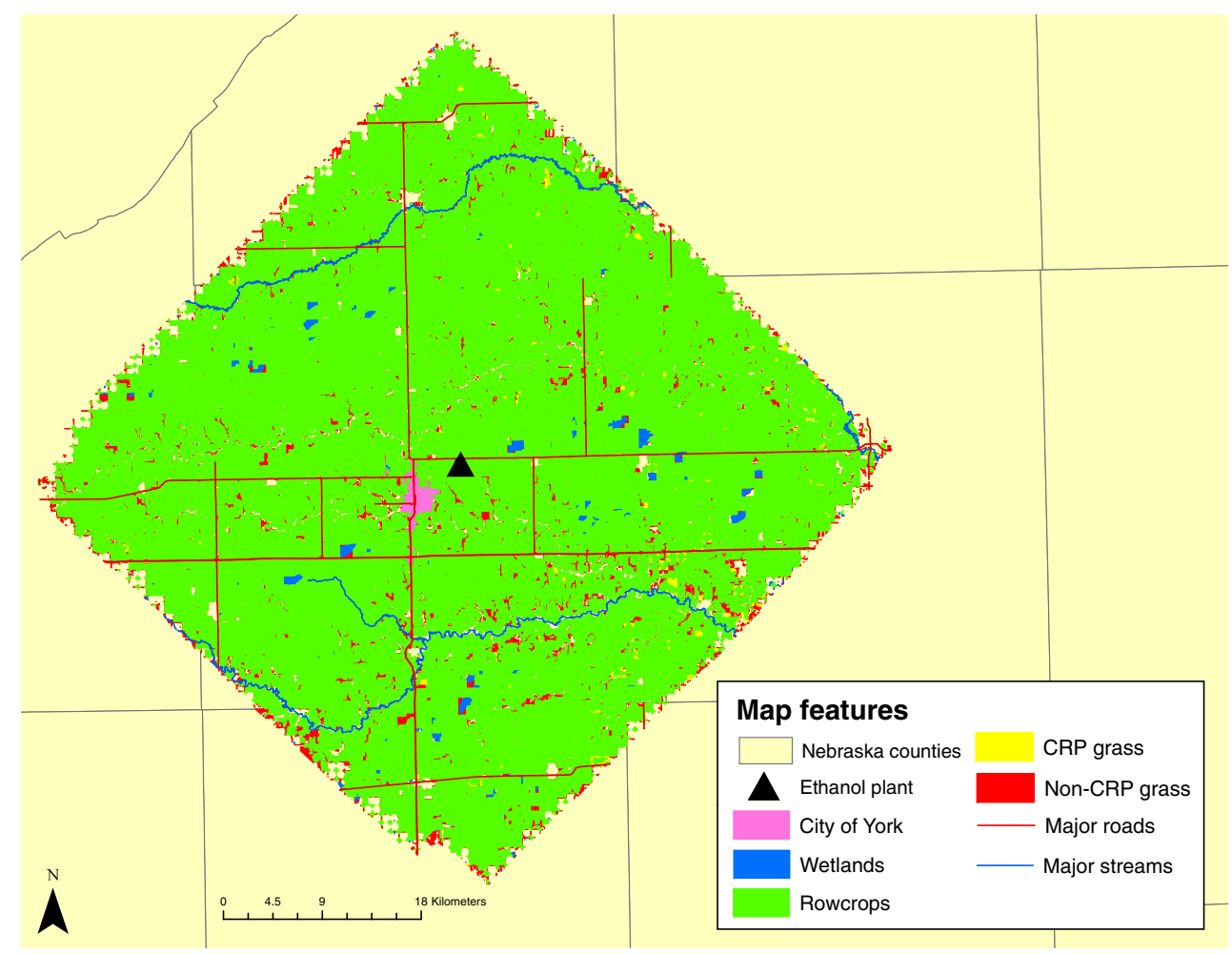




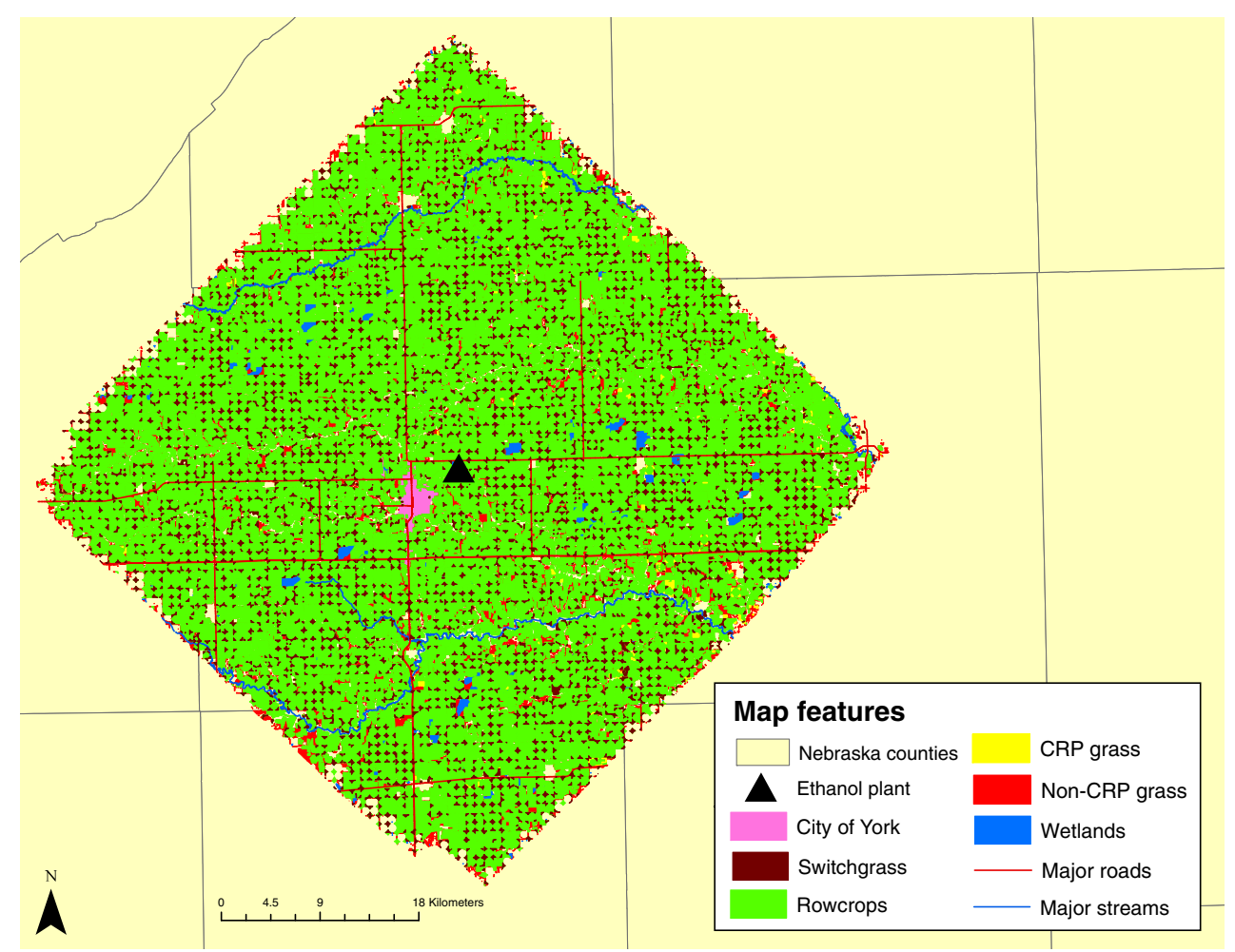

Fig. 2 Major landcover classes in the 40-km service area of an existing starch-based ethanol plant, following the conversion of some marginally productive cropland to bioenergy switchgrass. Rowcrop fields were grouped into marginality classes, according to irrigation type, size, shape, soils and likelihood of experiencing irrigation limitations in the future. $25-100 \%$ of marginality classes composed of non-irrigated fields on poor agricultural soils were converted to switchgrass, according to the number of marginal characteristics fields in the classes possessed. Unconverted rowcrop fields are the aggregation of all irrigated and nonirrigated rowcrop fields from Rainwater Basin Joint Venture (RWBJV) 2006 agricultural irrigation type data layer that were not converted to switchgrass. This figure was created in ArcGIS annual rowcrop production after the conversion of marginally productive agricultural lands to switchgrass by 0.5 . A 1:1 ratio of maize to soybean hectare for remaining annual rowcrops in the service area was assumed. Average maize grain yield for the plant service area was determined by averaging mean maize grain yields from the four Nebraska counties the service area occupies. A 1:1 weight distribution between maize grain and aboveground non-grain maize stover [8] was assumed, and mean maize grain and stover weight per hectare were considered equal. Mean maize grain and stover weight per hectare was obtained by multiplying mean maize grain yield per acre by 47 pounds, the dry matter (DM), or $0 \%$ moisture weight, of one bushel of maize grain [8], converting the result to kilograms ha ${ }^{-1}$ and then $\mathrm{mT} \mathrm{ha}{ }^{-1}$. Annual maize stover removal rates of 30 $50 \%$ were considered sustainable for maintaining soil chemistry $[8,10]$. To determine the maize stover weight range that could be collected per hectare at 30 and $50 \%$ removal rates, total maize stover weight per hectare was multiplied by 0.3 and 0.5 . Total maize stover weight available for annual removal from the existing starch-based ethanol plant service area was calculated by multiplying the upper and lower weight ranges of sustainably removable maize stover per hectare by the total number of maize-enrolled hectares in the service area.

Switchgrass biomass yields for the service area were assumed to average between 5 and $11 \mathrm{mT} \mathrm{ha}^{-1}$ [4]. These yields are very conservative, especially when considering yields of bioenergy-type switchgrass in the region have approached or exceeded $20 \mathrm{mT} \mathrm{ha}^{-1}$ [33]. The potential range in switchgrass biomass quantity for the service area was calculated by multiplying the total number of hectares considered suitable for switchgrass production by $5 \mathrm{mT} \mathrm{ha}{ }^{-1}$ and $11 \mathrm{mT} \mathrm{ha}^{-1}$. Total switchgrass and maize stover biomass weights for the service area were summed to determine the total quantity of biomass that could be sustainably supplied annually in this $40 \mathrm{~km}$ service area. Both maize stover and switchgrass biomass were assumed to have bioconversion efficiencies of $3341 \mathrm{mT}^{-1}[5,34]$, which are less than reported theoretical maximum bioconversion efficiencies for those crops [4]. Multiplying the total maize stover and switchgrass biomass yield range for the plant service area by $3341 \mathrm{mT}^{-1}$ yielded the potential range in cellulosic ethanol volume that could be sustainably produced annually within this defined $40-\mathrm{km}$ service area. 


\section{Results}

Mean 2010 maize grain DM yield for the four counties represented by the $40-\mathrm{km}$ service area was $9.074 \mathrm{mT} \mathrm{ha}^{-1}$. Assuming a 1:1 weight distribution between maize grain and stover results in the production of a mean 2010 maize stover weight of $9.074 \mathrm{mT} \mathrm{ha}^{-1}$. A stover removal rate of $30-50 \%$ allows for $2.72-4.54 \mathrm{mT}$ of stover to be sustainably collected annually. Of the 277,177 ha of cropland in the plant service area, 14,113 ha were found suitable for conversion to switchgrass, and the remaining 263,064 ha of non-bioenergy switchgrass cropland were assumed to consist of 131,532 ha of maize and 131,532 ha of soybeans. Multiplying the total number of bioenergy switchgrass enrolled hectares by the average switchgrass DM yield range of 5-11 $\mathrm{mT} \mathrm{ha}^{-1}$ results in a total switchgrass yield of 70,565-155,243 mT (Table 2). Multiplying the number of maize-enrolled hectares by the metric tons of maize stover available for removal per hectare results in an annual removal of 358,030-596,761 mT of maize stover (Table 3). The sum of switchgrass and maize stover supplies in the $40-\mathrm{km}$ plant service area is a total annual biomass production potential of 428,595-752,004 $\mathrm{mT}$. At a bioconversion efficiency of $334 \mathrm{l} \mathrm{mT}^{-1}$, the annual cellulosic ethanol production capacity of the ethanol plant is 143,150,730-251,169,336 liters.

\section{Discussion}

Sufficient quantities of biomass for year-round cellulosic ethanol production could be generated from maize stover and switchgrass in the $40-\mathrm{km}$ road network service area of the existing starch-based ethanol plant at current feedstock yields, sustainable removal rates and bioconversion efficiencies. In addition to the 208 million liters of starch-based ethanol already produced annually at the existing plant [35], another 143-251 million L of cellulosic ethanol could be produced annually from maize stover and switchgrass. Mitchell et al. (2012) recommended supplying 115-120\% of required biomass to cellulosic ethanol plants annually, in order to account for biomass yield variability and storage losses. The 428,595-752,004 $\mathrm{mT}$ of estimated annual

Table 2 Annual switchgrass biomass and ethanol production potential within the $40-\mathrm{km}$ road network service area of an existing starch-based ethanol plant, assuming $5 \mathrm{mT} \mathrm{ha}^{-1}, 11 \mathrm{mT} \mathrm{ha}^{-1}$, and $20 \mathrm{mT} \mathrm{ha}^{-1}$ switchgrass DM yields and an ethanol bioconversion efficiency of $334 \mathrm{l} \mathrm{mT}^{-1}$

\begin{tabular}{lll}
\hline $\begin{array}{l}\text { Switchgrass } \\
\text { yield }\left(\mathrm{mT} \mathrm{ha}^{-1}\right)\end{array}$ & Total biomass (mT) & $\begin{array}{l}\text { Ethanol } \\
\text { produced (l) }\end{array}$ \\
\hline 5 & 70,565 & $23,568,710$ \\
11 & 155,243 & $51,851,162$ \\
20 & 282,260 & $94,274,840$ \\
\hline
\end{tabular}

biomass produced within the ethanol plant service area provides $77-135 \%$ of the $556,990 \mathrm{mT}$ of biomass necessary to support a cellulosic ethanol plant with an annual ethanol output of 189 million L.

Total ethanol production estimates provided here assume the conversion of 14,113 ha of marginally productive agricultural lands to switchgrass within the plant service area $(\sim 5 \%$ of total cropland area). Without converting any land from rowcrops to switchgrass, the 138,589 maize-enrolled ha within the plant service area could supply 377,239$628,778 \mathrm{mT}$ of biomass annually at a stover removal rate of $30-50 \%$. This quantity of corn stover provides $68-113 \%$ of the $556,990 \mathrm{mT}$ of biomass necessary to support a cellulosic ethanol plant with an annual ethanol output of 189 million L. Because farmers may not be willing to plant switchgrass without an operational biorefinery already in place [5], maize stover may be utilized exclusively as a feedstock in the year of switchgrass planting. Even if marginally productive croplands are taken out of production and seeded to switchgrass, the 131,532 ha of remaining maizeenrolled cropland could supply 358,030-596,761 mT of maize stover biomass, or 64-107\% of the biomass necessary for supporting an ethanol plant with an annual ethanol output of 189 million L.

Development of biomass supply chains and bioconversion infrastructure are current logistical challenges facing advancement of the cellulosic ethanol industry. Management of feedstock delivery contracts between ethanol companies and farmers could increase the costs and difficulties associated with ensuring continual biomass supplies to ethanol plants. Even with established contracts, high grain prices and the appeal of shorter-term commitments could encourage farmers to continue raising annual rowcrops instead of switchgrass. Decreased productivity in drier years could increase the difficulty of obtaining sufficient biomass quantities for year-round production. Lastly, ethanol plants dependent on surrounding cropland for biomass could be outcompeted by larger plants, if methods for large-scale gathering and transportation of biomass are developed and implemented.

Although not considered in this analysis, grasslands enrolled in the CRP could be converted to bioenergy

Table 3 Annual maize stover biomass and ethanol production potential within the $40-\mathrm{km}$ road network service area of an existing starch-based ethanol plant, assuming a maize stover DM yield of $9.074 \mathrm{mT} \mathrm{ha}^{-1}, 30 \%$ and $50 \%$ annual maize stover removal rates, and an ethanol bioconversion efficiency of $3341 \mathrm{mT}^{-1}$

\begin{tabular}{llll}
\hline $\begin{array}{l}\text { Stover yield } \\
\left(\mathrm{mT} \mathrm{ha} \mathrm{ha}^{-1}\right)\end{array}$ & Removal \% & $\begin{array}{l}\text { Total } \\
\text { biomass }(\mathrm{mT})\end{array}$ & $\begin{array}{l}\text { Ethanol } \\
\text { produced (1) }\end{array}$ \\
\hline 9.074 & 30 & 358,030 & $119,582,020$ \\
9.074 & 50 & 596,761 & $199,318,174$ \\
\hline
\end{tabular}


switchgrass stands or back to annual rowcrops, and thereby contribute to biomass supplies in ethanol plant service areas. In the $40-\mathrm{km}$ service area of the existing starch-based ethanol plant, there are approximately 493 ha of CRP enrolled grassland. If removed from the CRP, these lands could yield an additional 2,465-5,423 $\mathrm{mT}$ of switchgrass or 1,342$2,237 \mathrm{mT}$ of maize stover biomass annually, which is $<1 \%$ of the biomass necessary to support a cellulosic ethanol plant with an annual ethanol output of 189 million liters.

In the future, switchgrass yields are projected to increase with the introduction of bioenergy specific cultivars and improved hybrids [33], which would increase the quantities of biomass supplied to ethanol plants (Table 2). Similarly, extending ethanol plant service areas to distances greater than $40 \mathrm{~km}$ would increase biomass supplies. Farmers may be willing to transport feedstocks farther than $40 \mathrm{~km}$ if economic incentives are provided and if there is only one plant producing cellulosic ethanol in the vicinity. Increased biomass supplies would make cellulosic ethanol production more feasible and less vulnerable to variations in annual biomass supply. Even without increased biomass supplies, supplying adequate biomass for year-round cellulosic ethanol production in the $40-\mathrm{km}$ service area of an existing starch-based ethanol plant appears to be feasible at current maize stover and switchgrass biomass yields and bioconversion efficiencies.

Results of this location-specific analysis provide insights into the feasibility of cellulosic ethanol production in landscapes throughout the Great Plains. In highly cultivated areas like the Rainwater Basin region of Nebraska, it is likely that maize stover will be readily available and utilized as a bioenergy feedstock, but large areas of marginally productive cropland are not available for conversion to switchgrass. Less intensively cultivated landscapes, which likely have a greater proportion of marginally productive agricultural lands, may be utilized to produce more switchgrass. If sufficient land area is enrolled in bioenergy switchgrass, grass-dominated landscapes could generate sufficient quantities of switchgrass biomass to supply feedstock to cellulosic ethanol plants. Regardless of whether maize stover or switchgrass is utilized as the primary feedstock at ethanol plants, cellulosic ethanol production could sustainably increase overall ethanol output in the Great Plains while minimizing competition with food resources. This study addressed the biomass producing potential for a single ethanol plant service area and determined that it is feasible to supply adequate biomass feedstock with maize stover and switchgrass in an intensively managed agricultural fuelshed. Similar, specific analyses should be conducted for additional proposed bioenergy facility locations.
Acknowledgments The authors would like to thank Eric Zach of the Nebraska Game and Parks Commission and two anonymous reviewers for their contributions to this manuscript, the Rainwater Basin Joint Venture for providing GIS data, and the Great Plains Landscape Conservation Cooperative and U. S. Geological Survey-Climate Effects Network for financial support. The Nebraska Cooperative Fish and Wildlife Research Unit is jointly supported by a cooperative agreement between the U. S. Geological Survey, the Nebraska Game and Parks Commission, the University of Nebraska - Lincoln, the U. S. Fish and Wildlife Service and the Wildlife Management Institute. Any use of trade, firm, or product names is for descriptive purposes only and does not imply endorsement by the U. S. Government.

\section{References}

1. Solomon BD, Barnes JR, Halvorsen KE (2007) Grain and cellulosic ethanol: history, economics, and energy policy. Biomass Bioenergy 31:4116-4425

2. Hill J, Nelson E, Tilman D, Polasky S, Tiffany D (2006) Environmental, economic, and energetic costs of biodiesel and ethanol biofuels. Proc Natl Acad Sci 103:11206-11210

3. Tilman D, Socolow R, Foley JA, Hill J, Larsen E, Lynd L, Pacala S, Reilly J, Searchinger T, Somerville C, Williams R (2009) Beneficial biofuels - the food, energy, and environmental trilemma. Science 325:270-271

4. Schmer MR, Vogel KP, Mitchell RB, Perrin RK (2008) Net energy of cellulosic energy from switchgrass. Proc Natl Acad Sci 105:464-469

5. Mitchell R, Vogel KP, Uden DR (2012) The feasibility of switchgrass for biofuel production. Biofuels 3:47-59

6. U.S. Environmental Protection Agency (2011) Renewable Fuel Standard. http://www.epa.gov/otaq/fuels/renewablefuels. Accessed 12 January 2012

7. Hovey H (2011) York on the short list: Abengoa's \$500 million vision could take shape in York County. Lincoln Journal Star. http://journalstar.com/news/state-and-regional/nebraska/article 72a62cb8-3263-58d0-9609-f1f444fb563d.html. Accessed $\overline{3}$ November 2011

8. Graham RL, Nelson R, Sheehan J, Perlack RD, Wright LL (2007) Current and potential U.S. maize stover supplies. Agron J 99:1-11

9. Willhelm WW, Johnson JMF, Karlen DL, Lightle DT (2007) Corn stover to sustain soil carbon further constrains biomass supply. Agron J 99:1665-1667

10. Sheehan J, Aden A, Paustian K, Killian K, Brenner J, Walsh M, Nelson R (2004) Energy and environmental aspects of using maize stover for fuel ethanol. J Ind Ecol 7:117-146

11. Jarecki MK, Lal R (2003) Crop management for soil carbon sequestration. Crit Rev Plant Sci 22:471-502

12. Dale VH, Kline KL, Wiens J, Fargoine J (2010) Biofuels: implications for land use and biodiversity. Biofuels and Sustainability Reports. Ecological Society of America, Washington D.C., U.S.A

13. Mitchell R, Wallace L, Wilhelm W, Varvel G, Wienhold B (2010) Grasslands, rangelands, and agricultural systems. Biofuels and sustainability reports. Ecological Society of America, Washington, D.C., USA

14. Dein BS, Jung H-L G, Vogel KP, Casler MD, Lamb JFS, Iten L, Mitchell RB, Sarath G (2006) Chemical composition and response to dilute-acid pretreatment and enzymatic saccharification of alfalfa, reed canarygrass, and switchgrass. Biomass Bioenergy 30:880-891

15. Vogel KP (2004) Warm-Season (C4) grasses. In: Moser LE, Burson BL, Sollenberger LE (eds) Switchgrass. ASA-CSSASSSA, Madison, WI, pp 561-588

16. Sarath G, Mitchell RB, Sattler SE, Funnell D, Pederson JF, Graybosch RA, Vogel KP (2008) Opportunities and roadblocks 
in utilizing forages and small grains for liquid fuels. $J$ Ind Microbiol Biotechnol 35:343-354

17. Sanderson MA, Brink GE, Higgins KF, Naugle DE (2004) WarmSeason (C4) grasses. In: Moser LE, Burson BL, Sollenberger LE (eds) Alternative uses of warm-season forage grasses. ASA-CSSASSSA, Madison, WI, pp 389-416

18. Gopalakrishnan G, Negri MC, Wang M, Wu M, Snyder SW, Lafreniere L (2009) Biofuels, land, and water: a systems approach to sustainability. Environ Sci Tech 43:6094-6100

19. McLaughlin SB, De La Torre Ugarte DG, Garten CT Jr, Lynd LR, Sanderson MA, Tolbert VR, Wolf DD (2002) High-value renewable energy from prairie grasses. Environ Sci Tech 36:2122-2129

20. Fargione J, Hill J, Tilman D, Polasky S, Hawthorne P (2008) Land clearing and the biofuel carbon debt. Science 319:1235-1338

21. Adler PR, Del Grosso SJ, Parton WJ (2007) Life cycle assessment of net greenhouse gas flux for bioenergy cropping systems. Ecol Appl 17:675-691

22. McLaughlin SB, Kszos LA (2005) Development of switchgrass (Panicum virgatum) as a bioenergy feedstock in the United States. Biomass Bioenergy 28:515-535

23. McGuire VL (2011) Water-level changes in the High Plains Aquifer, predevelopment to 2009, 2007-2008, and 2008-2009, and change in water in storage, predevelopment to 2009. U.S. Geological Survey Scientific Investigations Report 2011—5089, Reston, VA, U.S.A

24. Gilbert MC (1989) Ordination and mapping of wetland communities in Nebraska's Rainwater Basin Region. CEMRO Environmental Report 89-1. Omaha District, U.S. Army Corps of Engineers, Omaha, NE, U.S.A

25. Bishop AA, Vrtiska M (2008) Effects of the Wetland Reserve Program on waterfowl carrying capacity in the Rainwater Basin region of South-Central Nebraska. U.S. Department of
Agriculture-Natural Resources Conservation Service, Lincoln, NE., U.S.A

26. Pijanowski BC, Brown DG, Shellito BA, Manik GA (2002) Using neural networks and GIS to forecast land use changes: a Land Transformation Model. Comput Environ Urban Syst 26:553-575

27. Li R, Guan Q, Merchant J (2012) A geospatial modeling framework for assessing biofuels-related land-use and land-cover change. Agric Ecosyst Environ 161:17-26

28. Bonabeau E (2002) Agent-based modeling: methods and techniques for simulating human systems. Proc Natl Acad Sci 99:728-7287

29. An L (2012) Modeling human decisions in coupled human and natural systems: review of agent-based models. Ecol Model 229:25-36

30. Kiniry JR, Lynd L, Greene N, Johnson MV, Casler M, Laser MS (2008) Biofuels and water use: comparison of maize and switchgrass and general perspectives. In: Wright JH, Evans DA (eds) New research on biofuels. Nova Science, Hauppauge, NY, pp 17-30

31. Ricketts TH, Dinerstein E, Olson DM, Loucks CJ (1999) Terrestrial ecoregions of North America: a conservation assessment. Island, Washington D.C

32. Khanna M, Dhungana B, Clifton-Brown J (2008) Costs of producing miscanthus and switchgrass for bioenergy in Illinois. Biomass Bioenergy 32:482-493

33. Vogel KP, Mitchell RB (2008) Heterosis in switchgrass: biomass yield in swards. Crop Sci 48:2159-2164

34. Varvel GE, Vogel KP, Mitchell RB, Follet RF, Kimble JM (2008) Comparison of maize and switchgrass on marginal soils for bioenergy. Biomass Bioenergy 32:18-21

35. Nebraska Ethanol Board (NEB) (2011) Nebraska ethanol industry: ethanol plants in Nebraska. http://www.ne-ethanol.org/industry/ ethplants.htm. Accessed 12 January 2012 